\title{
INTER-ETHNIC RELATIONS IN KOSOVO
}

\section{Agon Demjaha}

State University of Tetovo and South East European University, a.demjaha@, seeu.edu.mk; agond@yahoo.com

DOI: $10.1515 /$ seeur-2017-0013

\section{Abstract}

The paper aims to analyse the state of inter-ethnic relations in Kosovo between ethnic Albanians and ethnic Serbs, with special focus on the period after unilateral declaration of independence of Kosovo in 2008. Inter-ethnic conflict in Kosovo has exclusively been over its territory since both Serbs and Albanians have made claims about history and ethno-demography to justify their alleged exclusive right to this ethnically mixed region. Consequently, inter-ethnic relations between Albanians and Serbs in Kosovo have been rather problematic throughout the most of the $20^{\text {th }}$ century. During this period Albanians in Kosovo have been subjected to discrimination, intimidation and even mass expulsion by Yugoslav/Serb authorities. In late 1990s, these relations between Albanians and Serbs in Kosovo have progressively worsened and finally escalated in an armed warfare in 1999.

Immediately after the war, Serbs in Kosovo were occasionally exposed to acts of inter-ethnic and retaliatory violence. Inter-ethnic relations between the two major ethnicities continued to be tense and fragile after independence of Kosovo in 2008. Dramatic changes of ethnic composition structure, atrocities and huge number of refugees due to the war, have left a legacy of deep mistrust and animosities between Albanians and Serbs in the newly created state. Consequently, Serbs in Kosovo have from the beginning refused to recognize Kosovo's independence and have rigorously refused any governance by Kosovo authorities. Serbian community, especially in the North, claims 
stronger territorial autonomy, even separatism and unification with Serbia. The paper claims that in Kosovo inter-ethnic and interstate relations are basically the components of the same equation. Therefore, paper concludes that only overall improvement of relations between Kosovo and Serbia could contribute to overall relaxation of inter-ethnic relations between Albanians and Serbs in Kosovo. Unfortunately, the latest incidents between Kosovo and Serbia have increased the tensions between the two sides to alarming levels.

Key Words: Inter-ethnic Relations, Conflict, Kosovo, Albanians, Serbs

\section{Introduction}

The violent dissolution of Former Yugoslavia has left a legacy of deep mistrust and animosities between majority and minority ethnicities in the newly created states that emerged out of it. In Kosovo, the roots of the interethnic conflict between Albanians and Serbs go back deep into history. For the most of the $20^{\text {th }}$ century, Albanians in Kosovo have been subjected to discrimination, intimidation and even mass expulsion by Yugoslav/Serb authorities. When Milosevic came to power in 1989, inter-ethnic relations between Albanians and Serbs in Kosovo progressively worsened and finally escalated into armed warfare. Immediately after the war in 1999, many Serbs were forced to leave Kosovo due to fears of inter-ethnic and retaliatory violence. After the declaration of independence in 2008, inter-ethnic relations between the two major ethnicities in the newly created state continued to be strained and fragile. The dispute over the number of remaining Serbs residing within Kosovo represents a highly burdening and unresolved issue. The issue at stake becomes even more sensitive in Kosovo, since the country has undergone dramatic changes of its ethnic composition structure due to the war, atrocities and huge number of refugees and internally displaced persons. On the other hand, Serbs in Kosovo, especially in the North, have from the beginning refused to recognize Kosovo's independence and have rigorously refused any governance by Kosovo authorities. In general, the Serbian community claims stronger territorial autonomy, while those who are living in the north of the country are highly prone to separatism and even unification with Serbia. Unfortunately, Belgrade authorities instead of encouraging the integration of Serbs in Kosovo, have been continuously pushing for nonintegrationist policies, in conjunction with normative definition of territories where the Serbian ethnic minority constitutes a majority. In the Western Balkans, inter-ethnic and interstate relations are basically the components of the same equation. Consequently, the inter-ethnic relations between Albanians 
and Serbs in Kosovo have constantly been held hostage by inter-state relations between Kosovo and Serbia. Thus, improvements or deteriorations of relations between Kosovo and Serbia have a direct impact on inter-ethnic relations in Kosovo. Despite the ongoing Brussels dialogue that has to certain extent improved relations between Belgrade and Prishtina, mistrust still prevails in bilateral relations between these two countries. Moreover, the latest incidents between Kosovo and Serbia have increased the tensions between the two sides to alarming levels.

The main aim of this paper is to analyse the state of inter-ethnic relations in Kosovo between ethnic Albanians and ethnic Serbs, with special focus on the period after the unilateral declaration of independence of Kosovo in 2008. The structure of the paper consists of four sections altogether, including introduction and conclusion. After the introduction, in the second section the paper will offer an overview of the overall inter-ethnic relations between Albanians and Serbs in Kosovo. The third section will then analyse the state of inter-ethnic relations between these two major communities in Kosovo after the declaration of independence, while at the same time trying to identify key factors that contribute to inter-ethnic tensions in the country. The paper ends with a concluding chapter that aims to summarize main findings of our analysis.

\section{Overview Of Inter-Ethnic Relations Between Albanians And Serbs In Kosovo}

The roots of the inter-ethnic conflict in Kosovo go back deep into history. Whereas Albanians consider themselves to be the descendants of the Illyrians, a people who lived in the Balkans before the arrival of the Romans, the Serbs consider Kosovo to be the territory of Old Serbia and the cradle of Serbia. Therefore, one might say that traditionally, the inter-ethnic conflict in Kosovo has exclusively been over its territory. Both sides, Serbs and Albanians, have made claims about history and ethno-demography to justify their alleged exclusive right to this ethnically mixed region. According to the Conferences of London (1913) and Versailles (1919), despite the free will of the majority of its people (Albanians), Kosovo became a part of the Kingdom of Yugoslavia. After the Second World War, in the Paris Conference (1946) it was decided that Kosovo should remain within newly established communist Yugoslavia, with certain a degree of autonomy within Serbia (Islami, 1994, p. 30). For the most of the $20^{\text {th }}$ century, Albanians in Kosovo have been subjected to discrimination, intimidation and even mass expulsion by Yugoslav/Serb authorities. After demonstrations of Albanians demanding republican status 
for Kosovo in 1968, the 1974 Yugoslav constitution gave Kosovo a significant autonomy. Although technically still within Serbia, in reality the province was granted a status similar to that of the constituent republics of the federation, which allowed for the political and cultural affirmation of Albanians. After Tito's death in 1981, a series of Albanian demonstrations once again asked for the elevation of the status of Kosovo into a republic within the federation. The demonstrations were brutally crushed by the special police and military forces. A state of emergency was declared and a series of trials of mainly young Albanians followed, with heavy jail sentences being imposed (Demjaha, 2000, p.33). Officially, in these clashes there were 57 victims but the real figure could have run into hundreds. In the eight years following the demonstrations, more than half a million Kosovar Albanians were at one time either arrested or questioned (Judah, 2008, p. 58). When Milosevic forcibly swept away Kosovo's autonomy in 1989, the conflict reached a new stage of intensity, and practically overnight Albanians were dismissed from their jobs, denied education in their own language, and exposed to a massive abuse of their human rights and civil liberties (Demjaha, 2000, p.33).

Faced with a de facto apartheid, Albanians in Kosovo engaged in a nonviolent campaign to win their right to self-determination ((Demjaha, 2000, p.34). On July 2, 1990, 114 out of 123 Albanian members of Kosovo's parliament, which had earlier and under duress voted to extinguish Kosovo's autonomy, now cast their ballots to establish Kosovo as a republic on equal terms with the six other Yugoslav republics. On September 7, 1990 the Kosovar deputies, meeting secretly in Kacanik, voted for a constitution for their republic. At this point independence was not on the agenda because, although the war had started, Yugoslavia still existed. When, during 19901991, Slovenia and Croatia prepared for independence and the Yugoslav state finally disintegrated, the Kosovo Albanians claimed the right to selfdetermination and proclaimed the sovereign and independent Republic of Kosovo. In the 1991 referendum deemed illegal by the Serbian authorities, almost 100 per cent of the Albanian population in Kosovo supported the idea of an independent state (Calic, 2000, p. 22). On the other hand, the Serbian authorities insisted on Kosovo's constitutional status as an integral part of Serbia. Despite warnings by numerous scholars and political observers about a potential escalation of the violence, the international community proved unable to prevent it. Consequently, from February 1998 onwards Kosovo was engulfed in a full-scale armed conflict between the Albanian guerrilla Kosova Liberation Army (KLA) on one side and the Serbian special police force as well as regular units of the Yugoslav military on the other (Calic, 2000, p. 19). 
Between March and October 1998, 1,900 Albanians and 170 Serbian and military personnel were killed, 650 Albanians were missing, around 4,0000 houses, shops, and schools were destroyed, and hundreds of thousands of Albanian civilians were forced to leave their homes (Demjaha and Peci, 2015, p. 154). With television images of impoverished families set to spend a freezing winter in plastic shelters, the international community decided to get seriously involved in searching for a diplomatic solution. A peace conference was organized at Rambouillet, France, during February 1999, and the two sides were invited to participate. Peace talks were suspended on $19^{\text {th }}$ of March, when Albanians unilaterally signed the peace deal, while Serbia rejected it altogether. With the situation in Kosovo deteriorating rapidly, in the early hours of the $24^{\text {th }}$ of March 1999, NATO launched the first air strikes against Yugoslavia. After two weeks, NATO laid down five non-negotiable demands to Milosevic: a cessation of Serb military action in Kosovo; the withdrawal of Serb military, police and paramilitary units; the stationing of an international military presence in the province; the safe return of refugees; and a willingness by Milosevic to discuss Kosovo's political future 'on the basis of the Rambouillet Accords' (Press release M-NAC-1(99)51, 1999). After 78 days of military air campaign that targeted Serbian military forces and infrastructure, on the $3^{\text {rd }}$ of June 1999, the FRY Parliament ratified the Ahtisaari-Chernomyrdin Plan, which included a total (verifiable) withdrawal of FRY military forces from Kosovo, the safe return of all refugees, and an UN-based civil mission to implement the Rambouillet Agreement's peace plan, which would be secured by NATO troops (Kllokoqi et al., 2008, p. 4). However, the consequences of the war were tragic: at least 10,000 people were killed, some 800,000 became refugees or displaced persons, and large parts of the country were devastated (Calic, 2000, p. 19). On the other hand, the mandate of the United Nations Mission in Kosovo (UNMIK) that aimed to administer Kosovo without prejudging its external status was almost unprecedented by the standards of UN field operations. Not only was it empowered to assume full interim administrative responsibility over the territory of Kosovo, it was also given a central political role in setting the conflict (Alexandros, 2004, p. 67).

Since the international community perceived the war as an ethnic conflict, "multiethnicity" was one of the basic goals of the international presence in Kosovo. While UNMIK always asked for tolerance and mutual respect between different communities in Kosovo, in reality the international administration strategy led to more segregation between Albanians and Serbs. Under UNMIK administration "Serb enclaves" were created, with "Northern Kosovo" being 
the biggest and the most troublesome one (Kllokoqi et al., 2008, p. 12). Such reality, coupled with bitter war memories, has continuously generated inter-ethnic tensions with sporadic episodes of violence. On 17 March 2004, violent riots erupted, triggered by an incident along the dividing line between Northern and Southern Mitrovicë/Mitrovica. The riots were directed against ethnic Serbs and Serb religious and cultural monuments in many parts of Kosovo (Weller, 2008, p. 19). This was the worst violence since the end of the war in Kosovo and left nineteen dead, with nearly 900 injured; over 700 Serb, Ashkali and Roma homes, up to ten public buildings and 30 Serbian churches and two monasteries were damaged or destroyed, and roughly 4,500 people displaced (ICG Europe Report No 155, 2004).

These riots showed that the status quo in Kosovo was not viable any longer, and therefore on $24^{\text {th }}$ of October 2005, the U.N. Security Council endorsed the recommendation of U.N. Secretary-General Kofi Annan to launch a political process to determine Kosovo's disputed status (Statement by the President of the Security Council, 2005). In November 2005, in agreement with the Security Council, the Secretary General appointed former Finnish President Martti Ahtisaari as his Special Envoy to lead the status negotiation process. On $26^{\text {th }}$ of March 2007, after more than a year of 15 rounds of unsuccessful United Nation-sponsored negotiations between Serbia and Kosovo to reach a political settlement on the status of Kosovo, the United Nations (UN) Secretary General Special Envoy Martti Ahtisaari prepared a Comprehensive Proposal for the Kosovo Status Settlement. While reiterating that independence was the only viable option, the report acknowledged Kosovo's limited capacity to ensure minority protection, to develop viable democratic institutions, to grow the economy, and to achieve interethnic reconciliation. Accordingly, Ahtisaari proposed that Kosovo's exercise of independence and its implementation of the concrete features of the Comprehensive Proposal should be "supervised and supported" by international civilian and military authorities. He urged a 'strong' but 'focused' international authority over community rights, decentralization, and protection of the Serbian Orthodox Church and the rule of law. These international authorities would have the power to 'correct actions', that is, to veto local governmental decisions that would "contravene the provisions of the Settlement proposal and the spirit in which they were crafted" (Report of the Special Envoy of the Secretary-General on Kosovo's Future Status, 2007). Such a proposal was vehemently opposed by Serbia and Russia, with the latter threatening to veto any possible resolution at the UN Security Council. Without further action in the U.N. Security Council, Kosovo's authorities prepared to make a declaration of independence in early 2008 as 
part of a process closely coordinated with the international community. On 17 February 2008, the Kosovo assembly adopted a declaration of independence "in full accordance with the recommendations of U.N. Special Envoy Martti Ahtisaari." The declaration declared Kosovo to be a democratic, secular, and multi-ethnic republic and fully accepted the obligations for Kosovo under the Ahtisaari proposal (Tansey, 2009, p. 159).

\section{Inter - Ethnic Relations In Kosovo After The Declaration Of Independence}

Since independence, inter-ethnic relations between Albanians and Serbs in Kosovo have remained rather tense and are still burdened by deep mutual mistrust and animosities. Serbs in Kosovo, especially in the North, have refused to recognize Kosovo's independence and have rigorously refused any governance by Kosovo. Similarly to all other countries of the region, disputes over the number of members of the minority communities that reside within Kosovo, was and still remains a highly burdening issue. This is especially true in Kosovo since the country has undergone dramatic changes of its ethnic composition structure, due to the war, atrocities and huge number of refugees and internally displaced persons. According to the last official census in Kosovo, in addition to the Albanian majority (92.9\%), there are also seven recognized ethnic groups as official minorities: Serbs (1.5\%), Bosniaks (1.6\%), Turks (1.1\%), Ashkali (0.9\%), Egyptians (0.7\%), Gorani (0.6\%), and Roma (0.5\%) (Kosovo Agency of Statistics, 2012). It should be mentioned though, that the results of the 2011 census were often contested and seen as controversial because they excluded the four Serb-majority northern municipalities of Leposaviq/Leposavić, Zubin Potok, Zvečan/Zveçan and North Mitrovica. Partially, this was due to the fact that Serbia was not interested in calling on Serbs from the north of Kosovo to participate in the census. Instead, Serbia pledged to conduct its own census in the north of Kosovo in order to determine the number of Serbs living there (Karadaku, 2011). On the other hand, the results were also criticized by the Kosovo Academy of Arts and Science that claimed that the actual number of Albanians in Kosovo is higher than shown by the census. Consequently, the census did not meet the expectations of ethno-national elites and institutions in both Kosovo and Serbia, since both saw it as a means of legitimizing the nationalist discourse of the other (Beha, 2014, p. 86). Nevertheless, while other minorities have basically integrated well into the new reality of independent Kosovo, it is the relation between Albanians and Serbs that causes the main inter-ethnic tensions in the country. 
As already suggested, the number of Serbs living in Kosovo represents the initial source of discord between the two communities. Serbs claim much higher numbers, especially of those who left Kosovo after 1999. According to the Kosovo census from 1981, there were 77.4 percent Albanians, 13.2 percent Serbs and 9.3 percent members of other communities living in the province. The latest census organized in former Yugoslavia in 1991, showed that the total population of Kosovo was 1,956,196. According to the estimate of former Federal Institute of Statistics, there were 1596072 (81.6 percent) Albanians (who actually did not participate in the census), while the second largest community was the Serbian one, with 194,190 inhabitants (9.9 percent) (Djukanovic, 2008, p. 2). Following the conflict in 1999, a considerable number of Serbs and other minorities left Kosovo and moved to Serbia. However, figures regarding this issue are quite different and contradictory. According to the Serbian Government 230,000 Serbs have left Kosovo, while ICG figures state that 97,000 Serbs have remained in Kosovo after the war, and around 100,000 have fled. On the other hand, according to European Stability Initiative (ESI), 130,000 Serbs are still living in Kosovo, which accounts for $2 / 3$ of the total pre-war Serbian population in Kosovo (OSCE Mission in Kosovo, 2010, p. 241; European Stability Initiative, 2004, p. 2). Moreover, the Serb population in Kosovo has continuously changed both because of their return to Kosovo and because many continue to leave due to the economic uncertainty in Kosovo and their perceptions that a more sustainable future is available outside of Kosovo.

While the number of the Serbian minority remains a highly controversial issue and a source of continuous tensions between Serbia and Kosovo, the reality shows that numbers are not the main driving force of inter-ethnic tensions between Albanians and Serbs. Namely, though the majority of Serbs in Kosovo live outside "Northern Kosovo" it is the latter that sparks major problems in the country. While Serbs living in other parts of Kosovo have been much more cooperative and have slowly began to integrate within the Kosovo reality, the northern part of Kosovo continues to be characterized by tensions and periodical outbreaks of violence. In addition, the divided town of Mitrovica has continuously been a hotspot of inter-ethnic tensions and became a synonym for an unresolved conflict in the northern part of Kosovo (Brand and Idrizi, 2012, p. 4). The situation has deteriorated further after Kosovo's declaration of independence, since Serb leaders in the North have rigorously refused any governance by Kosovo. As a result, different circles have often proposed partition of the North from Kosovo or a 'territorial swap' with Southern Serbia, as a modality to overcome the status quo. Yet such 
proposals have at least formally been rejected by both Kosovo and Serbia. Prishtina rejects the idea of partition, claiming that Kosovo's borders cannot be compromised, and the North, though currently not under full control, remains an integral part of its territory. Though intimately, many Albanians both in Kosovo and Southern Serbia might be ready to accept the idea of the 'territory swamp', Kosovo leaders are aware that such step would open the so-called 'Pandora's Box' that would further encourage Serbs in Bosnia and Albanians in Macedonia. On the other hand, by accepting partition, Belgrade would basically have to recognize the loss of the rest of Kosovo. Moreover, such partition or 'territory swamp' would undoubtedly trigger ethnic cleansing of the 60 percent Kosovo Serbs living south of the Ibar river (Rossi, 2014, p. 871).

It should be mentioned that Kosovo's constitution recognizes the 'groupdifferentiated rights' of Kosovo Serbs as the biggest minority in Kosovo. Namely, Article 57.1 of Chapter III of the Kosovo Constitution regarding Rights of Communities and their Members, clearly states that "Inhabitants belonging to the same national or ethnic, linguistic, or religious group traditionally present on the territory of the Republic of Kosovo (Communities) shall have specific rights as set forth in this Constitution in addition to the human rights and fundamental freedoms provided in chapter II of this Constitution." (Constitution of the Republic of Kosovo, 2008, p. 16). On the other hand, Ahtisaari's proposal stipulates extensive minority rights that even go beyond those included by the Council of Europe Framework Convention for the Protection of National Minorities (FCNM). For instance, Serbian is an official language throughout Kosovo, including areas where the Serb community is not a majority (Report of the Special Envoy of the Secretary-General on Kosovo's Future Status, 2007). In addition, the legislative framework in Kosovo has sought to invest communities and their members with advanced rights of effective participation. These include the right to form political parties, and guaranteed representation at all levels of government. In the central government, community participation is assured through guaranteed representation in the Kosovo Assembly, the Government, the judiciary and other bodies. Consequently, 20 out of 120 seats of the Assembly of Kosovo are guaranteed for representation of communities that are not in the majority in Kosovo. The Kosovo Serb Community is entitled to a minimum of 10 guaranteed seats (even if the number of seats won in an open election is less than 10), while an additional 10 seats are guaranteed to members of other communities in the country (Constitution of the Republic of Kosovo, 2008, p. 57). At the local level, in municipalities where at least 10 percent of municipal citizens belong to communities not in the majority 
in that municipality, a post of Deputy Chairperson for Communities will be reserved in the Municipal Assembly for a representative of those communities (Constitution of the Republic of Kosovo, 2008, p. 19). It should be mentioned that the Ahtisaari plan was implemented to a large extent in the south of Kosovo. However, no visible progress has been achieved in the four northern Serb-majority municipalities that basically refuse any formal cooperation with Kosovo institutions.

However, the inter-ethnic relations between Albanians and Serbs in Kosovo have constantly been held hostage by inter-state relations between Kosovo and Serbia. Actually, one might say that inter-ethnic and interstate relations in and between individual countries of the Western Balkans are the components of the same equation. Therefore, it was clear that improvements or deteriorations of relations between Kosovo and Serbia would have a direct impact on inter-ethnic relations in Kosovo. Consequently, the UN General Assembly Resolution 64/29 of September 2010 attributed the EU the responsibility to facilitate a process of dialogue between Pristina and Belgrade. According to the Resolution, the General Assembly "welcomes the readiness of the European Union to facilitate a process of dialogue between the parties; the process of dialogue in itself would be a factor for peace, security and stability in the region, and that dialogue would be to promote co-operation, achieve progress on the path to the European Union and improve the lives of the people." (UN Doc. A/RES/64/298, 2010). Since March 2011, under the auspices of the EU several rounds of negotiations between the two countries have taken place focusing on regional cooperation, freedom of movement, and rule of law. During these negotiations, the parties have reached agreement on free movement of persons, customs stamps, recognition of university diplomas, cadastre records, civil registries and Integrated Border Management (IBM) (Curri and Loshi, 2013, p. 74). Nevertheless, despite evident progress of the dialogue between Kosovo and Serbia facilitated by the EU, the governance or status of the North was not immediately put on the agenda. Kosovo, Serbia and the EU have decided that tackling the North's governance or status is too difficult before more efforts were made to secure cooperation on improving the region's socioeconomic development, security and public order (ICG Europe Report, 2011, p. i).

Still, in mid-January 2013 the Serbian government adopted and the parliament endorsed a platform for talks with Prishtina which in fact accepts Kosovo's territorial integrity and jurisdiction over the North. The platform called for the creation of an "Autonomous Community of Serbian Municipalities", comprised by the North and six other Serb-majority municipalities elsewhere 
in Kosovo. Though such a Community would have broad self-governing powers, it would still be integrated into the Kosovo legal system and apply Kosovo law. Although the platform and the parliament's resolution repeat Serbia's traditional rejection of Kosovo's independence, it is clear that Serbia's government is attempting to accept and work with the de facto reality of a sovereign Kosovo, while setting aside de jure recognition of independence (ICG Europe Report, 2013, pp. 8-9). On the $19^{\text {th }}$ of April 2013, under the auspices of the European Union, Kosovo and Serbia signed "The First Agreement of Principles governing Normalization of Relations." The 15 point Agreement aims at integrating Kosovo Serb majority municipalities of Northern Kosovo (Leposiviq, Northern Mitrovica, Zvecan and Zubin Potok), into the constitutional and legal system of Kosovo through establishment of an Association/Community of Serb majority municipalities. Accordingly, the Association/Community would have "full overview of the areas of economic development, education, health, urban and rural planning" (The First Agreement, 2013). Once established, the Association/Community membership would also be open to all other Serb majority municipalities upon request. Among others, the Agreement also guarantees integration of all Serbian security structures in the North into Kosovo institutions, thus implying that there will be only one Kosovo Police Force. However, the Police Regional Commander would be a Kosovo Serb appointed by the Kosovo Ministry of Internal Affairs from the list provided by the Association/ Community (The First Agreement, 2013). Although the agreement was initially fiercely opposed by opposition in both Serbia and Kosovo, it was afterwards approved by the parliaments in Belgrade and Prishtina.

The EU and other major international actors such as the US, OSCE, NATO and the UN have hailed the agreement as a historic break-through for KosovoSerbia relations and stabilization processes in the rest of Western Balkans (Economist, 2013). Clearly, successful implementation of this agreement could contribute to the normalization of relations between Kosovo and Serbia on the one hand, and Serbs and Albanians in Kosovo on the other. Undoubtedly, the normalization of relations between Kosovo and Serbia would have a huge impact on the integration of the Serb community into Kosovo society. The agreement has shown certain positive signs in the North as well. After being encouraged by leaders of Serbia, Serbs in the North have participated in great numbers in the last parliamentary elections in Kosovo held in June 2014. According to Kosovo's Central Election Commission, the overall turnout in the four northern municipalities was 42 percent, just a little less than the overall turnout throughout Kosovo (Rettman, 2014). 
On the 25th of August 2015, Kosovo and Serbia finalized four new agreements on the establishment of an Association/Community of Serbian Municipalities, energy, telecommunications, and the freedom of movement of the Mitrovica Bridge. However, though these agreements were supposed to be implemented during 2016, in practice this has not happened. Especially the establishment of the Association/Community has proven to be the most disputable part of the agreement. The opposition parties have fiercely criticized the agreement, fearing a de facto federalization of the country as well as interference of Serbia in Kosovo's internal affairs. The main opposition parties have staged several violent demonstrations in the capital of Prishtina, while at the same time constantly setting off tear gas in the parliament (Pugliese, 2016). The latest incidents have further deteriorated the relations between Kosovo Albanians on the one hand, and Serbia and Serbs in Northern Kosovo, on the other. The building of the concrete wall in northern Mitrovica by the Serb authorities (Balkan Insight, 2016), the arrest of a former Kosovo PrimeMinister, Ramush Haradinaj, in Paris, and the attempt of Belgrade authorities to operate a direct train between Belgrade and northern Mitrovica decorated with nationalist slogans, have spiked the tensions between the two sides to alarming levels. The train incident has actually prompted one of the most hostile exchanges between the two sides since the war in 1999 (Salem, 2017). The Kosovo authorities have qualified Serbia's effort to operate a railway link between the two countries as a provocation and an aggressive violation of its sovereignty. The Prime Minister of Serbia, Aleksandar Vucic, has on the other hand, accused Kosovo authorities of attempting to blow up the railway line as well as of sending Special Forces to attack the train (Balkan Insight, 2017). Meanwhile, Serbs living in Kosovo have expressed serious fear and concern for their security and their future. They have accused both Belgrade and Prishtina for using them as pawns in their continuous power games (Zaba and Morina, 2017). Clearly, overall improvement of relations between Kosovo and Serbia could undoubtedly contribute to the overall relaxation of inter-ethnic relations between Albanians and Serbs in Kosovo, and eventually play a positive role in finding effective solutions that would diffuse tensions in the North.

\section{Conclusion}

The roots of the inter-ethnic conflict in Kosovo go back deep into history, and one might conclude that traditionally, the inter-ethnic conflict in Kosovo has exclusively been over its territory. Both sides, Serbs and Albanians, have made claims about history and ethno-demography to justify their alleged 
exclusive right to this ethnically mixed region. For most of the $20^{\text {th }}$ century, Albanians in Kosovo have been subjected to discrimination, intimidation and even mass expulsion. During the 1990s, faced with a de facto apartheid, Albanians in Kosovo engaged in a non-violent campaign to win their right to self-determination. However, this policy of non-violence was not rewarded either by the Serbian authorities or by the international community. Despite many warnings that the conflict in Kosovo would escalate into open armed conflict, no steps were taken to prevent it. Consequently, Kosovo was engulfed in a full-scale armed conflict between the Albanian guerrilla KLA and the Serbian special police and military forces. After the war, the international administration strategy led to more segregation between Albanians and Serbs. Under UNMIK administration "Serb enclaves" were created, with "Northern Kosovo" being the biggest and the most troublesome one. Such a reality, coupled with bitter war memories, has continuously generated inter-ethnic tensions with sporadic episodes of violence.

Since independence, inter-ethnic relations between Albanians and Serbs in Kosovo have remained rather tense and are still burdened by deep mutual mistrust and animosities. Serbs in Kosovo, especially in the North, have refused to recognize Kosovo's independence and have rigorously refused any governance by Kosovo authorities. Clearly, the inter-ethnic relations between Albanians and Serbs in Kosovo have constantly been held hostage by inter-state relations between Kosovo and Serbia. Thus, improvements or deteriorations of relations between Kosovo and Serbia have a direct impact on inter-ethnic relations in Kosovo. The signing of "the First Agreement of Principles governing Normalization of Relations" between Kosovo and Serbia as part of the EU facilitated dialogue was seen as historic break-through in this direction. However, practical implementation of the agreement, especially the establishment of the Association/Community of Serbian Municipalities, has proven to be extremely difficult. Moreover, it may be concluded that the latest incidents of building of the concrete wall in northern Mitrovica, the arrest of a former Kosovo Prime-Minister and the attempt of Belgrade authorities to operate a direct train between Belgrade and northern Mitrovica decorated with nationalist slogans, have spiked the tensions between the two sides to alarming levels. The train incident has actually prompted one of the most hostile exchanges of accusations between the two sides since the war in 1999 and raised fears among Serbs in Kosovo. It may be concluded that only an overall improvement of relations between Kosovo and Serbia could contribute to the overall relaxation of inter-ethnic relations between Albanians and Serbs in Kosovo. 


\section{References}

- Beha, A. (2014). Minority Rights: An Opportunity for Adjustment of Ethnic Relations in Kosovo?. Journal on Ethnopolitics and Minority Issues in Europe, 13(4), 85-110.

- Brand, J. \& Idrizi, V. (2012, February). Grass-root Approaches to Inter-Ethnic Reconciliation in the Northern Part of Kosovo. Prishtina: Kosovar Institute for Policy Research and Development.

- Calic, M. J. (2000). Kosovo in the twentieth century: A historical account. In Ramesh Thakur and Albrecht Schnabel ed., Kosovo and the Challenge of Humanitarian Intervention: Selective Indignation, Collective Action, and International Citizenship. Tokyo: United Nations University Press.

- Constitution of the Republic of Kosovo (2008, June 15). Prishtina: Assembly of the Republic of Kosovo.

- Curri, F. \& Loshi, M. (2013). Monitoring Regional Cooperation in South East Europe: Country Report - Kosovo. In Stefan Dehnert and Dane Taleski (eds.) Monitoring Regional Cooperation in South East Europe, Berlin: Friedrich Ebert Stiftung.

- Demjaha, A. \& Peci, L. (2015). Insurgencies in the Balkans: Albanian Liberation Armies. In Albrecht Schnabel and Rohan Gunaratna eds. Wars From Within: Understanding and Managing Insurgent Movements. London: Imperial College Press.

- Demjaha, A. (2000). The Kosovo Conflict: A Perspective from Inside. In Albrecht Schnabel and Ramesh Thakur eds. Kosovo and the Challenge of Humanitarian Intervention: Selective Indignation, Collective Action, and International Citizenship. Tokyo: United Nations University Press.

- Djukanovic, D. (2008, October 2-4). The Post-conflict Integration of Minority Ethnic Communities in Kosovo. Third Annual Conference on Human Security, Terrorism and Organized Crime in the Western Balkan Region, Belgrade: HUMSEC.

- European Stability Initiative (2004, June 7). The Lausanne Principle: Multiethnicity, Territory and the Future of Kosovo's Serbs. Berlin/Prishtina: European Stability Initiative.

- First Agreement of Principles Governing Normalization of Relations. (2013, April 19). The office of the Prime Minister, The Republic of Kosovo. Retrieved from http://www.kryeministriks.net/repository/docs/FIRST AGREEMENT_OF_PRINCIPLES_GOVERNING THE_NORMALIZATION_OF RELATIONS, APRIL 19,2013 BRUSSELS en.pdf

- International Crisis Group (2011, March 14). North Kosovo: Dual Sovereignty in Practice. ICG Europe Report No 211, Pristina/Belgrade/Brussels.

- International Crisis Group (2013, March 19). Serbia and Kosovo: The Path to Normalisation. ICG Europe Report No 223, Pristina/Belgrade/Brussels. 
- International Crisis Group (2004, April 22). Collapse in Kosovo. ICG Europe Report No 155, Pristina/Belgrade/Brussels.

- Islami, H. (1994). Demographic Reality of Kosovo. In Dusan Janjic and Shkelzen Maliqi, eds., Conflict or Dialogue: Serbian-Albanian Relations and Integration of the Balkans. Subotica: Open University, European Civic Centre for Conflict Resolution.

- Judah, T. (2008). Kosovo: What Everyone Needs to Know. Oxford: Oxford University Press.

- Karadaku, L. (2012, October 16). Kosovo completes 2011 census without data from north. SETimes. Retrieved from http://www.setimes.com/ cocoon/setimes/xhtml/en_GB/features /setimes/features/2012/10/16/ feature-04

- Kllokoqi, S., Ahmeti, B., Konjufca, G. \& Valon Murati (2008). The Role of Human and Minority Rights in the Process of Reconstruction and Reconciliation for State and Nation-Building: Kosova. Human and Minority Rights in the Life Cycle of Ethnic Conflicts, Bozen-Bolzano: European Academy.

- Kosovo Agency of Statistics (Agjencioni i Statistikave të Kosovës, ASK) (2012). Rezultatet përfundimtare të regjistrimit të popullsisë 2011[Final Results of 2011 Census]. Prishtina.

- Organization for Security and Cooperation in Europe (2010). Kosovo Communities Profiles. Prishtina: OSCE Mission in Kosovo.

- Press release M-NAC-1(99) 51 (1999, April 12).

- Pugliese, M. (2016, March 8). The uncertain future of the Association of Serb majority municipalities in Kosovo. Nationalia, Retrieved from http://www.nationalia.info/new/10733/the-uncertain-future-of-the-association-of-serb-majority-municipalities-in-kosovo

- Rettman, A. (2014, June 10). Ethnic Serbs vote as normal in Kosovo elections. EU Observer, Retrieved from http://euobserver.com/foreign $/ 124538$

- Rossi, M. (2014). Ending the impasse in Kosovo: partition, decentralization, or consociationalism?. Nationalities Papers: The Journal of Nationalism and Ethnicity, 42(5), 867-889.

- Salem, H. (2017, January 24). Kosovo, Serb dispute threatens to derail Balkan peace," Politico, Retrieved from http://www.politico.eu/article/eukosovo-serbia-train-dispute-eu-mogherini-vucic-thaci/

- Serbia Accused of Provoking Kosovo over Train. (2017, January 16). Balkan Insight, Retrieved from http://www.balkaninsight.com/en/article/serbia-accused-of-provoking-kosovo-over-train-01-16-2017

- Serbia and Kosovo: A Breakthrough at Last (2013, April). The Economist, Retrieved from http://www.economist.com/blogs/easternapproaches/2013/04/serbia-and-kosovo-0 
- Tansey, O. (2009). Kosovo: Independence and Tutelage. Journal of Democracy, 20(2), 153-166.

- United Nations (2007, March 26). Report of the Special Envoy of the Secretary-General on Kosovo's Future Status. S/2007/168.

- United Nations (2010, September 9). Doc. A/RES/64/298, New York: United Nations.

- United Nations Security Council (2005, October 24). Statement by the President of the Security Council. UN Doc S/PRST/2005/51.

- Weller, M. (2008). Negotiating the Final Status of Kosovo, Chaillot Paper No. 114, Paris: Institute For Security Studies.

- Yannis, A. (2004). The UN as Government in Kosovo. Global Governance: A Review of Multilateralism and International Organizations, 10(1), 6791.

- Zaba, N. \& Morina, D. (2017, January 19). Kosovo's Serbs Feel Frightened, Insecure and Misused. Balkan Insight, Retrieved from http://www. balkaninsight.com/en/article/kosovo-s-serbs-feel-frightened-insecureand-misused-01-19-2017 